TRABALHO INFANTIL EM ODISHA OCIDENTAL E ESTUDO DE CASOS

\title{
CHILD LABOUR IN WESTERN ODISHA \& CASE STUDIES
}

\section{RESUMO}

\author{
Dr. Samir Kumar Nanda
}

Ministry of Labour \& Employment, Govt. of India

A conceitualização dos fatores de produção como terra, trabalho, capital e organização já não é um fenômeno aceitado. Além de terra, a força de trabalho, o maquinário e a gestão sao os verdadeiros parceiros da produção no sistema econômico moderno. A inclusão de leis trabalhistas e esquemas do governo enriqueceram o cenário trabalhista em Odisha ao longo de sua história. O National Child Labour Project (trad. Projeto Nacional do Trabalho Infantil) tem tido um papel fundamental para a identificação, rehabilitação e integração de mão-de-obra infantil nas últimas três décadas. Baseando-se em investigação em Odisha, na Índia, esse artigo descreve a situação de trabalho infantil no estado. Odisha tornou-se um estado próprio em primeiro de abril de 1936. Oitenta e dois anos depois, relações trabalhistas e a situação da mão-de-obra infantil assim como a de trabalhadores migrantes em Odisha sofreu grandes mudanças. O artigo também aborda a magnitude do problema do trabalho infantil e os passos tomados pelo governo para eliminá-lo.

Palavras-chave: Trabalho infantil. Odisha ocidental. NCLP, integração. STC, migração.

\begin{abstract}
The traditional concept of factors of production namely land, labour, capital and organisation are no more accepted phenomenon. Apart from land, the manpower, machine and management are the actual partners of production in modern economic system. Inclusion of various labour laws, schemes by the Government have enriched the labour scenario of Odisha since its inception. National Child Labour Project plays a vital role for the identification, rehabilitation and mainstreaming of the child labour during last three decades. Based upon research in the state of Odisha in India, this article describes the child labour scenario in the state of Odisha. Odisha became separate state on 1st April 1936.Eighty-two years since the momentous day, much has changed in the Labour relation, Juveniles, Child Labour problem \& Migrant Workers of Odisha. This article also explains the magnitude of child labour and steps taken by the Government to eliminate child labour Problem of child labour is very sensitive.
\end{abstract}

Keywords: Child Labour. Western Odisha. NCLP, Mainstreaming. STC, Migration 


\section{INTRODUCTION}

"Children resemble the fragrant flowers of the universe". They have the right to flourish, they are the gift of the God". Today's child is tomorrow's citizen. So many lofty and rosy words we are using for the children, yet we are helpless for their interests. The development of a country is solely dependent on the welfare of the children. In most of the developing and underdeveloped countries the children are deprived of their right to enjoy their childhood. Child labour is one of the most violated human rights issues and therefore it is universally condemned. Over the years, there has been a growing concern among different social partners on the prevalence of child labour, whereby thousands of children are deprived of their essential qualities of childhood and are forced as cheap substitutes for adults. Despite its vast natural and human resources and substantial progress achieved during the last 50 years plan of development, Odisha continues to be one of the less developed States in India.

\section{History of Child Labour}

World famous Novelist Charles Dickens had highlighted the exploitation of children and juvenile in different factories of England. Although the condition of different countries has improved yet the exploitation of children remain as usual.According to the history child labour was not a new phenomenon in the world. During $3^{\text {rd }}$ century the great Economist Kautilya has mentioned about the existence of child labour. He has described in his "Arthashastra" that child labours were working like slaves whose age were below 8 years of age.

In the past in our country it is also seen that the students in "Gurukuls" were engaged in cleaning and sweeping of the premises of the Ashrams. In addition to that they collect water, firewood and engage in cattle care. The Gazetteer of Calcutta, August11,1831 had reported the case of two minor girls fleeing from domestic service, who had been bought and employed as slaves [ Sinha,1991:3]. But independent India is bowed under the weight of sheer magnitude. Millions of children continue to work regularly. 


\section{Western Odisha}

Western Odisha comprises the vast geographical and culturally homogeneous area of Odisha. Dakshin Kosala Kingdom is one of the several names by which this region was known in the ancient period, i.e. prior to the $5^{\text {th }}$ century A.D. The region exhibits a great degree of cultural uniformity in terms of demography and life-style, and extends from Kalahandi district in the south to the Sundargarh district in the northwest, thereby including whole of the pre-1993 districts of Sambalpur, Kalahandi, Sundargarh and Balangir district and some part of the then-undivided Koraput, Dhenkanal and Phulbani districts. The Sonepur, Balangir, Nuapada, and Kalahandi districts of this region are also part of Kalahandi Balangir Koraput or KBK. The whole Western Odisha includes ten districts of Odisha State namely-Balangir, Bargarh, Boudh, Deogarh, Jharsuguda, Kalahandi, Nuapada, Sambalpur, Sonepur \& Sundargarh districts. Despite its vast natural \& human resources and substantial progress achieved during the past 60 years of plan development, Western Odisha continues to be one of the less developed regions of Odisha with nearly $79 \%$ of its population depends on agriculture and nearly $48 \%$ live below the poverty line. The challenge before planning to devise programmes to transform a relatively underdeveloped economy characterized by high incidence of poverty and unemployment, low-per capita income, inadequate exploitation of abundant natural resources and inadequate development of socioeconomic infrastructure into a vibrant economy on the path to self-sustaining economic growth with equity.24.83\% of the total population of Odisha state resides in Western Odisha. Out of which 40\% are Tribal population. Around $10 \%$ of the population belong to Agharia community migrated from north-western Uttar Pradesh. It is found that around $23.38 \%$ of Scheduled castes and $33.9 \%$ Scheduled Tribes population of Odisha are residing in this region. This area has $29.75 \%$ of economically backward people of the total population of the state, $25.8 \%$ are cultivators, $27.52 \%$ are agricultural labourers, 32.18\% are house-hold industrial worker, 25.36\% are workers, $30.54 \%$ are marginal workers and $\mathbf{2 2 . 8 7 \%}$ are non-workers of the state of Odisha.

\section{Migration}

The contribution of migration in sustaining rural livelihoods in Odisha, cannot be denied. With declining agricultural incomes and inability of rural households to 
sustain with farming alone, the countryside in Odisha is witnessing an emergence of what one can term "migrarian" livelihoods - where migration and agriculture form the major providers, accounting for more than 55-6o per cent of the annual incomes. The policy prescriptions on livelihoods, on the contrary, do not account for migration as a significant contributor to rural incomes. If anything, lack of a policy stands on internal migration and poor safeguards for labour interests have given way to a perverse migrant labour economy thriving on abundant and unregulated access to cheap rural labour from Odisha, easily recruited, circulated and cast away at will. The KalahandiBalangir-Koraput (KBK) region of Western Odisha has long been known for all the wrong reasons - starvation deaths, drought, famines, poverty and distress, and, over the past six years or so, Maoism. With unproductive landholdings and very few means of sustenance, the rural poor are plunged into crisis every year. Their only option is to migrate to other States in search of work. Among the most favoured destinations for them are the brick kilns firing the construction boom in cities such as Hyderabad. A well-entrenched chain of labour contractors and middlemen, starting from dons based in Andhra Pradesh and going down to touts located in the interior villages of the KBK districts, organise the trafficking of labour from these villages to the cities. Every year, after the 60-day paddy crop is harvested around the beginning of September, comes the festival of Nuakhai, meaning "eating new rice," an old tradition of Western Odisha. Poor families take an advance from the labour contractors at this time. Soon after, men, women and children start migrating in large numbers to pay off this advance by offering their labour to the contractors. They live on brick kiln sites in makeshift shanties, braving the harsh weather with no protection. With no toilets and no sources of drinking water, these sites are hotbeds of misery and disease. Sexual exploitation of women is rampant. On the journey, travelling with their belongings and children in overcrowded trains, people lose life and limb. Attempts to escape from the work site can meet with instant and ruthless reprisal as the two migrants found out. Children are preferred in the brick making industry because they are short, so while filling brick making frames with mud, they need not bend down like adults. Also, when freshly made bricks are piled up, there is no space for an adult to walk and overturn the bricks for drying. Children can walk on top of the bricks and overturn them without causing damage. So, the labour is contracted according to the traditional Pathariya system, where Pathariya is a work unit comprising a man, a woman and one or two children. And, in the process, every law of the land is violated to keep shining. 


\section{Methodology}

It is an empirical-analytical study. To make a review of related literatures, books \& journals were referred. For collection of data in a systematic manner questionnaire were prepared. With the help of a questionnaire and the interview schedule data were collected from the sample districts of Western Odisha. The author spent a lot of time in the area in different times of the year \& freely mixed with the parents of the child labour \& established good rapport with them. He was allowed to collect all relevant information about the parents and child labour. He also collected valuable data from the Sate Labour Department Officials, National Child Labour Project (NCLPs) and other related departments working in the area. The Instructors of NCLP schools, village level workers and the workers of NGOs have also supplemented lot of information regarding the socio-economic life of the child labours and their parents. Having classified and analyzed the field data the researcher tried to draw logical inferences and make some suggestions for the rehabilitation and elimination of child labour system from the Western Odisha.

\section{Meaning of child labour}

Fundamentally, the child labours are the child workers involved in the chores that are hazardous to their overall development. This vicious cycle results in their abuse and exploitation. Millions of child labours abound in higher percentage in Asian countries, Africa, USA \& Europe. They are primarily seen working in hazardous factories, policing shoes, hotels, field \& as domestic help. Considerable differences exist between the many kinds of work children do. Some are difficult and demanding, others are more hazardous and even morally reprehensible. Children carry out a very wide range of tasks and activities when they work.

\section{Definition of Child Labour}

The Child Labour (Prohibition and Regulation) Act,1986 defined child as labour who has not completed his 14 years of age. Whether parttime / full time in any occupation, engagement of child in the labour force simply means a complete or partial denial of childhood to him. He is not 
merely deprived of the jobs and carefree life of a child, but also of desirable mental and physical developments. This is not only injustice to him as child. but also, as adult throughout his life, for the foundation of his adulthood is built on extremely weak structure of under development. According to V. V. Giri, the term child labour is commonly interpreted in two different ways; First as a economic percale and secondly, as a social evil. The impact of work on child's development is the key to determining when such work becomes a problem. Work that is harmless to adults can be extremely harmful to children. In reality, children do a variety of works in widely divergent conditions.

UNICEF defines child labour as work that exceeds a minimum number of hours, depending on the age of a child and on the type of work. Such work is considered harmful to the child and should therefore be eliminated.

\section{Review of Literature}

Dr R.N.Mishra has indicated in his study that, in Odisha the coastal districts with long coast line have affected regularly by natural calamities while the districts of Western Odisha are drought prone area. As $60 \%$ of the population of Odisha is under BPL Category therefore due to poverty child labour is engaged in various types of hazardous and non-hazardous sectors.

Nikhil Raj and Anoop Kumar Satpathy in their study of Household Food Insecurity and Child Labour: Some Evidences from Rural Odisha have thrown light on the cause of child labour in Western Odisha. According to them the sample survey conducted in the rural areas of the three districts(Sambalpur, Bargarh \& Balangir) of Western Odisha indicate that social and economic backwardness as reflected in terms of land ownership, caste of the households and the literacy levels of the heads of the households, apart from the family size determine the degree of food insecurity of households. The greater the intensity of this insecurity, the more the children would be forced to join work, even though it is a first option for only one-fifth of the households. The transition of households from the FISM (Food Insecurity with Hunger Moderate) To FISS (Food Insecurity with Hunger Severe)needs to be checked urgently to avoid further increase in the proportion of child labour. Analysis of household consumption expenditure shows that the standard of living of the households is higher 
in Bargarh and Sambalpur districts compared to Balangir district. Further the highest proportion of child labour was concentrated in households who fall in the lowest MPCE (Monthly Per Capita Consumer Expenditure) classes. Lastly, it was established beyond reasonable doubt that, though household food insecurity is a necessary condition for child labour, it is by no means, a sufficient one. For a higher incidence of child labour, other factors like relative levels of development of a district and existence of demand for labour, among others have to coexist simultaneously vis-à-vis household food security.

Mohapatra and Dash (2011) examined the socio-economic problem of child labour between the time periods (2009-2010). The major variables used in poverty, illiteracy, unemployment, low wages, ignorance, social prejudice, regressive tradition, poor standard of living, backwardness, superstation, low status of women have combined to give birth to the terrible practice of child labour of women have combined to give birth to the terrible practice of child labour. Method used in growth rate sample data through investigation or interview, they found that the migrant's family form various district of Odisha their social economic condition is very poor which make them to go for labour.

Mishra (2012) examined the Child Rights and Situation of Children in Odisha between the time periods 2010-2011. The major variable used income, education, standard of living, lack of education, poverty, and unemployment etc, method used in this paper only secondary data. He found that migrant family and uneducated adults generally send their children to work in an early age.

\section{Magnitude of child labour}

Table-1 Magnitude of Child Labour in India, Odisha \& Western Odisha

\begin{tabular}{|c|c|c|c|}
\hline Census Year & India & Odisha & Western Odisha \\
\hline 1971 & $1,07,53,985$ & $4,92,477$ & $1,89,414$ \\
\hline 1981 & $1,36,40,870$ & $7,02,293$ & $2,70,112$ \\
\hline 1991 & $1,12,85,349$ & $4,52,394$ & $1,39,526$ \\
\hline 2001 & $1,25,91,667$ & $3,77,594$ & $1,09,276$ \\
\hline 2011 & $43,53,247$ & 92,087 & 75,440 \\
\hline
\end{tabular}

The above table shows the number of child labours detected in India, Odisha and Western Odisha during the census conducted in the year 1971,1981,1991,2001\& 2011.If 
we compare the above statistics we will find that in 1981 census maximum number of child labours identified at National level, State level and in Western Odisha also. If we go through the census report of 2011, we observe that the number of child labour has decreased in the country, Odisha and Western Odisha.

Table-2 Magnitude of Child Labour in Western Odisha

\begin{tabular}{|l|l|l|l|l|l|l|l|}
\hline $\begin{array}{l}\text { Survey } \\
\text { Year }\end{array}$ & 1971 & 1981 & 1991 & 1997 & 2001 & 2005 & 2011 \\
\hline $\begin{array}{l}10 \\
\text { districts } \\
\text { of } \\
\begin{array}{l}\text { Western } \\
\text { Odisha }\end{array}\end{array}$ & $1,89,414$ & $2,70,112$ & $1,39,526$ & 58,131 & $1,09,276$ & $1,49,299$ & 75,440 \\
\hline Trend & & $42 \%$ increased & $48 \%$ decreased & $58 \%$ decreased & $88 \%$ increased & $37 \%$ increased & $49 \%$ decreased \\
\hline
\end{tabular}

The above table indicates the number of child labours identified in the 10 Districts of Western Odisha during the year 1971,1981,1991, 2001\& 2011 Decadal Census and 1997 \& 2005 District Level Child labour Survey conducted by the National Child Labour Project \& District Administration. If we observe the trend of the above figures, we will find that, the percentage of child labour decreased to $48 \%$ in the year 1991 in comparison to $1981,58 \%$ in 1997 survey in comparison to 1991 census and $49 \%$ in the 2011 census in comparison to 2005 survey. But during the rest of the survey period there is an increasing trend. In the 1981 census percentage increased up to $42 \%$ than in 1971, in 2001 census the figure again increased to 88\% than 1997 survey and in 2005 survey it has been increased $37 \%$ in comparison to 2001 census.

\section{Table-3 Agricultural statistics of Western Odisha}

\begin{tabular}{|c|c|c|c|c|c|c|}
\hline \multirow[t]{2}{*}{$\mathrm{Sl}$} & \multirow[t]{2}{*}{ Districts } & \multirow{2}{*}{$\begin{array}{c}\text { Agricultural } \\
\text { Land } \\
\text { (In hector) }\end{array}$} & \multicolumn{2}{|c|}{$\begin{array}{l}\text { Irrigated Land } \\
\text { (In hector) }\end{array}$} & \multirow[t]{2}{*}{ Agricultural Products } & \multirow[t]{2}{*}{$\begin{array}{l}\text { Electrifi- } \\
\text { ed Village }\end{array}$} \\
\hline & & & Area & $\%$ & & \\
\hline 1 & Balangir & 32000 & 17920 & $56 \%$ & Paddy, Sugarcane, Groundnut \& Horse Gram & 1290 \\
\hline 2 & Bargarh & 348747 & 225904 & $65 \%$ & Paddy, Groundnut & 1154 \\
\hline 3 & Boudh & 95142 & 42483.47 & $45 \%$ & Paddy, Pulses & 522 \\
\hline 4 & Deogarh & 66795 & 16032 & $24 \%$ & Paddy, Wheat, Sugarcane & 356 \\
\hline 5 & Jharsuguda & 298886 & 134498 & $46 \%$ & $\begin{array}{l}\text { Paddy, Oilseeds, Vegetable, } \\
\text { Condiments, Pulses }\end{array}$ & 380 \\
\hline
\end{tabular}




\begin{tabular}{|l|l|l|l|l|l|l|}
\hline 6 & Kalahandi & 272000 & 108800 & $40 \%$ & $\begin{array}{l}\text { Rice, Wheat, Sesame, Coffee, } \\
\text { Sugarcane, Jowar, Maize }\end{array}$ & 907 \\
\hline 7 & Nuapada & 189170 & 56943 & $30 \%$ & Paddy & 481 \\
\hline 8 & Sambalpur & 194020 & 56466 & $29 \%$ & Paddy & 1037 \\
\hline 9 & Sundargarh & 336000 & 117600 & $35 \%$ & Paddy & 1220 \\
\hline 10 & Sonepur & 135415 & 70415 & $52 \%$ & Paddy & 613 \\
\hline
\end{tabular}

If we go through the above table, we can find that Bargarh is the highly irrigated district whereas Deogarh is the lowest irrigated district in the Western Odisha. However, number of villages electrified in Balangir District is maximum and Deogarh district is the minimum. In almost all districts paddy is the important agricultural products except in Kalahandi districts. However, Kalahandi district is producing maximum agricultural products.

\section{Table-4 Details of Children and enrolment in Western Odisha}

\begin{tabular}{|c|c|c|c|c|c|}
\hline $\begin{array}{c}\text { Sl. } \\
\text { No }\end{array}$ & Districts & $\begin{array}{c}5-14 \\
\text { populations }\end{array}$ & $\begin{array}{c}\text { No. of Primary \& U.P } \\
\text { Schools }\end{array}$ & $\begin{array}{c}\text { Enrolmen } \\
t\end{array}$ & $\begin{array}{c}\text { Out of } \\
\text { School }\end{array}$ \\
\hline 1 & Bargarh & $2,90,084$ & 2,325 & $2,17,324$ & 72,760 \\
\hline 2 & Balangir & $3,01,583$ & 3,290 & $2,61,461$ & 40,122 \\
\hline 3 & Boudh & 84,780 & 1,025 & 78,714 & 6,366 \\
\hline 4 & Deogarh & $\mathbf{6 5 , 3 6 7}$ & $\mathbf{7 8 0}$ & $\mathbf{5 4 , 7 1 2}$ & $\mathbf{1 0 , 6 5 5}$ \\
\hline 5 & Jharsuguda & $\mathbf{1 , 1 5 , 8 1 2}$ & 947 & 84,357 & 31,455 \\
\hline 6 & Kalahandi & $3,07,070$ & 2,985 & $2,71,980$ & 35,090 \\
\hline 7 & Nuapada & $1,27,649$ & 1,445 & $1,20,300$ & 7,349 \\
\hline 8 & Sambalpur & $2,09,180$ & 1,724 & $1,20,300$ & 7,349 \\
\hline 9 & Sonepur & $1,27,180$ & 1,221 & $1,43,875$ & 65,305 \\
\hline & Sundargar & & & & \\
10 & h & $4,34,316$ & 3,441 & 92,087 & 35,093 \\
\hline & Total & $\mathbf{2 0 , 6 3 , 0 2 1}$ & $\mathbf{1 9 , 1 8 3}$ & $\mathbf{1 4 , 4 5 , 1 1 0}$ & $\mathbf{3 , 1 1 , 5 4 4}$ \\
\hline
\end{tabular}

If we make an analysis of the above table it can be seen about the number of children in Western Odisha who are out of school. About 14,45,110 numbers of children out of a total of 20,63,021 children have been enrolled in 19,183 numbers of Primary and U.P Schools in 10 districts of Western Odisha. The rest 3,11,544(15\%) of children are out of school. It can be observed in the table that Deogarh District around 10,655(16\%) children per year are out of school. If such a large number of children of 5-14 age group do not attend the school then what they actually do? The answer is either they help their parents at home or they must be engaged at work for wages.

\section{National Child Labour Project (NCLP)}


The National Child Labour Project (NCLP) Scheme is a Central Sector Scheme. Under this Scheme the District Project Societies (DPS) are set up at the district level under the Chairmanship of the Collector/District Magistrate for overseeing the implementation of the project. Under this Scheme, the children in the age group of 914 years are withdrawn from work and put into NCLP Special Training Centres, where they are provided with bridge education, vocational training, mid-day meal, stipend, health care etc. before being mainstreamed into formal education system. The children in the age group of 5-8 years are directly linked to the formal education system through a close coordination with the Sarva Shiksha Abhiyan. Further, to ensure the effective enforcement of the provisions of the Child Labour Act and smooth implementation of NCLP Scheme, a dedicated online portal named PENCiL (Platform for Effective Enforcement for No Child Labour) is developed in order to make the NCLP successful through better monitoring and implementation ensuring the timely disposal of work with transparency. Under this Scheme, funds are provided directly to the District Project Societies who in turn engage and allocate the funds to NGOs/Voluntary Agencies/Civil Societies Organisation etc. for running of Special Training Centres.

\section{The NCLP Scheme seeks:}

To eliminate all forms of child labour through identification and withdrawal of all children in the Project Area from child labour, Preparing children withdrawn from work for mainstream education along with vocational training, Ensuring convergence of services provided by different government departments/agencies for the benefit of child and their family.

To contribute to the withdrawal of all adolescent workers from Hazardous Occupations / Processes and their skilling and integration in appropriate occupations through identification and withdrawal of all adolescent workers from hazardous occupations / processes, facilitating vocational training opportunities for such adolescents through existing scheme of skill developments. Raising awareness amongst stakeholders and target communities, and orientation of NCLP and other functionaries on the issues of 'child labour' and 'employment of adolescent workers in hazardous occupations/processes and Creation of a Child Labour Monitoring, Tracking and Reporting System. 
NCLP is a central sector scheme where $100 \%$ of the funding is provided by the Government of India through the Ministry of Labour and Employment. Funds under the existing NCLP scheme are released by the Central Government directly to the registered NCLP District Project Society under the chairpersonship of the administrative head of the district namely District Magistrate/District Collector (DM/DC)/Deputy Commissioner of the district who is under administrative control of the State Govt.1.28 million children have been mainstreamed to formal education since the inception of National Child Labour Project (NCLP) scheme.Till 9th Plan 100 Projects were sanctioned for covering about 0.211 million children in 13 States. Under the Scheme 4002 schools has been sanctioned in 100 NCLPs. During the Ninth Plan 4,00,200 working children have been covered under the scheme. About 0.308 million children have been mainstreamed into formal education system till 2012. On the basis of census figures of 2001, other new 100 districts have been identified for setting up of NCLPs during the Tenth Plan. In the Eleventh Plan Period another 21 districts were included in the NCLP scheme. Presently, NCLPs are functioning in 313 districts in 21 states in India.

\section{Impact Evaluation}

After implementation of NCLP scheme in Western Odisha many changes took place among the identified child labour. During the period from 1994 to 2010 around 1,62,305 child labours have been identified in Western Odisha out of which 83,042 students have been enrolled through NCLP Special Training Centres which is $51 \%$ of the total child labour. $87 \%$ of child labour students enrolled have been mainstreamed into higher education after passing from NCLP Special Training Centres during the period which is $45 \%$ of the total Child labour identified. About $53 \%$ of the students enrolled in NCLP Special Training Centres have undergone Vocational Training for self-employment after being educated which is $27 \%$ of the total child labour identified in the Western Odisha after implementation of NCLP Scheme. So NCLP Scheme had played a major role for the rehabilitation, identification, elimination and mainstreaming of the child labour in Western Odisha. The Project Directors \& the Programme Managers of the National Child Labour Projects of 24 NCLP districts play an important role for the success of the project. National Child Labour Project of Odisha has conducted State Level Sports Meet of the students of 24 NCLP districts for 
seven times. The child labour students of NCLP Special Training Centres have many Government jobs after mainstreaming.

\section{Table-5 Details of National Child Labour Project (NCLP) in WesternOdisha}

\begin{tabular}{|c|c|c|c|c|c|}
\hline Districts & $\begin{array}{c}\text { Date of } \\
\text { commencement }\end{array}$ & Registration No. & $\begin{array}{c}\text { No. of NCLP } \\
\text { Schools } \\
\text { sanctioned }\end{array}$ & $\begin{array}{c}\text { No. of } \\
\text { schools } \\
\text { opened }\end{array}$ & $\begin{array}{c}\text { Sanctioned } \\
\text { Strength }\end{array}$ \\
\hline Bargarh & 04.12 .1995 & $601 / 190 /(95-96)$ & 40 & 40 & 2000 \\
\hline Balangir & 30.01 .1996 & $3347-837(95-96)$ & 40 & 40 & 2000 \\
\hline Boudh & No NCLP & ----- & ---- & ---- & ---- \\
\hline Deogarh & o8.09.1995 & $27 /(95-96)$ & 20 & 40 & 2000 \\
\hline Jharsuguda & 07.09 .1995 & $190-44(95-96)$ & 50 & 50 & 2750 \\
\hline Kalahandi & 14.11 .1995 & $1528 / 79(95-96)$ & 50 & 50 & 2500 \\
\hline Nuapada & 16.09 .1995 & $113 / 32$ & 20 & 20 & 1000 \\
\hline Sambalpur & 29.04 .1994 & $46866(95-96)$ & 70 & 40 & 3500 \\
\hline Sonepur & Jan,1997 & $128 / 29(95-96)$ & 40 & 40 & 200 \\
\hline Sundargarh & 2007 & ----- & 40 & 40 & 2000 \\
\hline
\end{tabular}

The above table describes us regarding the creation of NCLP schools in different districts of Western Odisha. In Odisha the first NCLP was inaugurated in Sambalpur district in the year 1994 however, in other districts NCLP started after 1995. Primarily, in the year 1994 only one NCLP was there and in 1995 NCLP schools were started in 17 districts and in the year 2002 another 06 NCLP districts have been functioned. In Western Odisha NCLP started in five districts in the year 1995, in Balangir during the year1996, in Sonepur in the year 1997 \& in Sundargarh in the year 2007. The number of NCLP schools sanctioned for Sambalpur district is 70 because under Sambalpur NCLP 02 blocks were adopted of Sambalpur district and one block of Jharsuguda Subdivision. But, in 1995 Jharsuguda became a separate district. As per the present status Jharsuguda and Kalahandi districts have maximum number of schools and Nuapada district has minimum number of Schools. No NCLP has yet been opened in Boudh district.

Table-6 Enrolment/Rehabilitation of Child Labour through NCLP in Western Odisha

\begin{tabular}{|l|l|l|l|l|l|l|}
\hline $\begin{array}{l}\text { Number } \\
\text { Districts }\end{array}$ & $\begin{array}{l}\text { Enrolment of Child Labour in } \\
\text { NCLP centres }\end{array}$ & & \\
\hline & $\begin{array}{l}1994-95 \\
\text { to }\end{array}$ & $\begin{array}{l}2000-01 \\
\text { to } \\
2004-05\end{array}$ & $\begin{array}{l}2005-06 \\
\text { to } \\
2009-10\end{array}$ & $\begin{array}{l}\text { Total } \\
\text { Enrolment }\end{array}$ & $\begin{array}{l}\text { Identified } \\
\text { Child } \\
\text { Labour }\end{array}$ & $\begin{array}{l}\text { \% } \\
\text { Labour }\end{array}$ \\
\hline
\end{tabular}




\begin{tabular}{|c|c|c|c|c|c|c|}
\hline $\begin{array}{l}\text { Number } \\
\text { Districts }\end{array}$ & $\begin{array}{l}\text { Enrolm } \\
\text { NCLP }\end{array}$ & $\begin{array}{l}\text { t of Chi } \\
\text { tres }\end{array}$ & Labour in & & & \\
\hline & $\begin{array}{l}1999^{-} \\
2000\end{array}$ & & & & & $\begin{array}{l}\text { Enrolled/ } \\
\text { Rehabilitated by } \\
\text { NCLP }\end{array}$ \\
\hline 08 & 20423 & 24358 & 27702 & 72483 & \multirow{4}{*}{162305} & \multirow{4}{*}{$51 \%$} \\
\hline Balangir & \multicolumn{4}{|l|}{10559} & & \\
\hline Boudha & 0 & 0 & 0 & 0 & & \\
\hline Total 10 & 20423 & 24358 & 27702 & 83042 & & \\
\hline
\end{tabular}

In the whole Western Odisha maximum number of child labour enrolled in the year 1995-96 and minimum in the year 1997-98. Out of 1,62,305 number child labours identified in the Western Odisha 83,042 number child labours i.e., around 51\% have already been rehabilitated till 2009-10 through only NCLP. So far, the case of Deogarh district is concerned out of 14,924 number of child labours identified around 9,390(63\%) child labours have been enrolled in the NCLP Schools during the said time period and Deogarh comes in 3rd position in Western Odisha in enrolment and rehabilitation through NCLP. From this analysis we can conclude that NCLP School plays an important role for the rehabilitation of child labour in Western Odisha.

\section{Vocational Training}

Vocational Training has been given special emphasis in the NCLP scheme. The reason is that the children enrolled are mainly in the older age group of 9-14 years and have had previous work experience. It was also felt that choice of vocational training should be available to those children who wish to take up skill-based work after the initial training in the special training centres.

Table-7 Enrolment for Vocational Training in Western Odisha

\begin{tabular}{|c|c|c|c|c|c|c|c|c|}
\hline $\begin{array}{l}\text { Number } \\
\text { of } \\
\text { District } \\
\mathrm{s}\end{array}$ & $\begin{array}{l}1994 \\
- \\
1999\end{array}$ & $\begin{array}{l}1999^{-} \\
2004\end{array}$ & $\begin{array}{l}2004^{-} \\
2009\end{array}$ & Total & $\begin{array}{l}\text { Enrolmen } \\
\mathrm{t}\end{array}$ & $\begin{array}{l}\text { Identificatio } \\
\mathrm{n}\end{array}$ & $\begin{array}{l}\% \text { of } \\
\text { Enrolmen } \\
t\end{array}$ & $\begin{array}{l}\text { \%of } \\
\text { identificatio } \\
n\end{array}$ \\
\hline 08 & 2790 & $\begin{array}{l}1104 \\
6\end{array}$ & $\begin{array}{l}2098 \\
1\end{array}$ & 34817 & 83042 & 162305 & $53 \%$ & $27 \%$ \\
\hline $\begin{array}{l}\text { Balangi } \\
\mathrm{r}\end{array}$ & & & & 9487 & & & & \\
\hline Boudh & O & O & o & o & & & & \\
\hline \multicolumn{4}{|c|}{10 Districts } & $\begin{array}{l}4430 \\
4\end{array}$ & & & & \\
\hline
\end{tabular}


Number of child labour students undergone Vocational Training in the different NCLP of the Western Odisha are given above. Almost all the districts have provided more than one type of Vocational training and all the trades are self dependent trades and all are related to local needs. As per the data available Nuapada NCLP has provided vocational training to maximum number of child labour students in term of enrolment. Likewise, Bargarh NCLP ranked the lowest in term of both enrolment and identification of child labour students. In the whole Western Odisha $53 \%$ of child labour students had undergone Vocational Training in term of enrolment and $27 \%$ in term of identification. Again, all the NCLP districts have adopted the education system same as SSA which make clear that both NCLP and SSA students are getting equal opportunity in the field of education. In Deogarh district 40 NCLP Schools are functioning where Vocational Training in the trades of Tailoring, Cycle repairing, Commercial Art \& Painting and Tasar Reeling, Spinning \& Weaving are being imparted to the students. So far, the Vocational figure of Deogarh district is concerned it is $31 \%$ of the enrolment of child labour and $20 \%$ of the total child labour identified in the district. As Boudha district has no NCLP therefore the Vocational Training in the said district does not arise. So, from this table we can see that the child labour identified in Western Odisha have undergone vocational training through which they can become self dependent.

\section{Mainstreaming (Mainstreaming of Child Labour through NCLP)}

The main purpose of the NCLPs is to mainstream the children rescued from work either into regular schools or else in the vocational stream and subsequently, on reaching legal age for employment, in acceptable and productive work, suited for their aptitude and skills. Priority to these children in admission to residential schools such as those under the Kasturba Gandhi Balika Vidyalaya scheme, Ashram School hostels etc would help in retention of these children in the mainstream schools. The district administration / State Government is required to oversee this crucial support to children rescued from work and admitted to NCLPs Special Training Centres.

Table-o8 Mainstreaming in Western Odisha

\begin{tabular}{|l|l|l|c|c|}
\hline $\begin{array}{l}\text { Number of } \\
\text { Districts }\end{array}$ & Year & $\begin{array}{l}\text { Number of } \\
\text { Mainstreaming }\end{array}$ & \% of Enrolment & $\begin{array}{l}\text { \% } \\
\text { identification }\end{array}$ \\
\hline 09 & $\begin{array}{l}1995-96 \\
\text { To } \\
2011-12\end{array}$ & 55,986 & & \\
\cline { 2 - 3 } & $2012-2014$ & 16,250 & $87 \%$ & $45 \%$ \\
\hline
\end{tabular}


The number of Child labour students mainstreamed from NCLP Schools into higher education after completion of three academic years in the sixteen states of India and Odisha up to the academic session 2011-12 and Western Odisha up to the academic session 2013-14 is indicated in the above table. So far, the whole Western Odisha is concerned around $87 \%$ of child labour students mainstreamed through NCLP in terms of enrolment and $45 \%$ of students mainstreamed in term of total identified child labour in the whole Western Odisha. If we see the data of Deogarh district we find that the percentage of child labours mainstreamed is $100 \%$ (12444) in terms of enrolment and $56 \%$ (22087) in terms of total child labour identified in the district.

\section{Causes of child labour}

In all the districts poverty is the main reason and next to it is illiteracy. However, alcoholism, socio-economic conditions, drought, lack of industry and awareness generation as well as family tradition are also among the causes of child labour in some districts. From the information of Deogarh district we can see that poverty and alcoholism are the main reasons in increase of child labour system.

Not merely poverty, but social \& economic factors sometimes influence the parents' decision for sending the children to work or the school. Maximum parents stated a lot of reasons of child labour. Having more numbers of children, migration due to lack of works in the villages, alcoholism and bad habits of the elders, using of girl children to assist their mother at home and taking care of younger siblings, low wages, illiteracy of parents, inability of the sick \& unhealthy parents on feeding their children, severe economic problems, family debts, barren lands \& waste lands, high rate of interest on loans are all the reasons.

\section{Consequences}

The consequences of Child labour system in Western Odisha are Educational deprivation, creating of more poor people, illiteracy, bad impact on the society and retarded children growth. 


\section{Remedial measures}

As per the data available in the study awareness among the people, financial assistance to poor, close watch by District Level Task Force, proper implementation of the act, increasing literacy rate of people, increasing the earning capacity of the poor and rapid inspection of the act can only eliminate the problem.

\section{Awareness Generation Programme}

According to the study it can be observed the impact of the awareness generation programme on the evil of child labour system. It is also clear that awareness among people can help for elimination of child labour system in the Western Odisha. Again, we can also see that the child labour can be mainstreamed into higher education and become success like other children in the society. In Deogarh district awareness programmes like Rallies, Padayatra, Publication in News Papers and programme in District festival are being a result of which public became aware of the evil practices of child labour. About 1269 families of child labours have been included in anti poverty programmes of the Government. Till date more than 1000 child labours students of NCLP have qualified HSC Examination and some of them have admitted in Sports Hostel.

\section{Inferences}

Here we found that in Western Odisha $79 \%$ of people depend upon agriculture \& $48 \%$ live below poverty line. Not merely poverty but social \& economic factors, more numbers of children, migration, low wages, illiteracy, family debts, family tradition, less industries, castism are the main causes of child labour. Deogarh has the highest population of child labour in Western Odisha.

40\% of populations of western Odisha are tribal. Deogarh district has the highest child labour population in Western Odisha \& lowest irrigated district. No. of electrified villages also found less in Deogarh district. Only NCLP in the Western Odisha plays an important role for the identification, rehabilitation, mainstreaming of child labour. If we go through the consequences of child labour, we find here that educational 
deprivation, creating of more poor people, illiteracy, bad impact on society are found here. Awareness programme, poverty alleviation programme, implementation of labour laws can only eliminate child labour in Western Odisha.

$15 \%$ of children in Western Odisha \& 16\% in Deogarh district are out of school. Again, in Western Odisha 15.6\% villages \& in Deogarh district 22\% villages have no school. Around 79932 ST children are out of schools in Western Odisha for different reasons. Out of which $43 \%$ are due to engagement at home \& $15 \%$ are engaged for earn of money. It is found that the NCLP scheme plays a vital role for rehabilitation of child labour \& attraction of child labour to the schools with stipend, MDM, study materials \& sports activities. The NCLP scheme only works in Western Odisha for the rehabilitation. Out of 1,62,305 numbers of child labours identified in Western Odisha, $51 \%$ have been rehabilitated through NCLP, out of which $55 \%$ have been, mainstreamed into formal education through NCLP only.

Employers disliked Labour Inspector visits and made the children run away as soon as they reached there for inspection. Employers do not allow them to interrogate child workers regarding age, hours of work, payment of wages etc.

About $85 \%$ of parents say that if they will be provided with works on a regular basis then they will send their children to schools instead of sending them to works. They also stated that while they are migrated to the other states to earn living at that time the children are also accompanying them. In the neighbouring states as no facilities of study in the Oriya languages available therefore they forced to engage the children in the works to earn money.

\section{Case Study-1}

In this case it is found that due to poverty how the parents forced to work the children and how the children opposed it. Rairakhol is a Block positioned in Sambalpur district in Odisha. Positioned in rural region of Odisha, it is one of the 9 blocks of Sambalpur district. According to the government records, the block number of Rairakhol is 25 . The block has 214 villages and there are total 13430 homes in this Block. As per Census 2011, Rairakhol's population is 55833. Out of this, 28021 are males while the females count 27812 here. This block has 7047 kids in the age group of o-6 years. Among them 3623 are boys and 3424 are girls. Literacy rate in Rairakhol block is $66 \% .36974$ out of total 55833 population is educated here. In males the literacy rate is $75 \%$ as 21016

@rquivo Brasileiro de Educação, Belo Horizonte, v. 9, n. 18, 2021 
males out of total 28021 are literate however female literacy rate is $57 \%$ as 15958 out of total 27812 females are literate in this Block. The Negative side is that illiteracy rate of Rairakhol block is 33\%. Here 18859 out of total 55833 persons are illiterate. Male illiteracy rate here is $24 \%$ as 7005 males out of total 28021 are illiterate. In females the illiteracy rate is $42 \%$ and 11854 out of total 27812 females are illiterate in this block. The count of working person of Rairakhol block is 27946 however 27887 are nonworking. And out of 27946 employed person 6675 peoples are entirely reliant on agriculture.

Two children namely Bikash Munda, aged about 10+ and Madan Munda aged about 9+ of Chatuni Village in Charmal Police Station area under Rairakhol Block of Sambalpur District were studying in Class-V and IV respectively. Both of them are brothers and they are living with the widowed mother. Both the children are from poor family. Due to abject poverty the mother discontinued their study and one day forced them for cow grazing. But both the sons opposed their mother's decision and denied to do so. They told that they want to continue the study. They were very much interested to go to school. But the poor mother became angry, abused them and beaten up them. As a result of which one day both the sons left home and went to Sambalpur by walk which is about 55 Kilo Metre away. On the way they arrived Naxapali village and asked a hotel owner for food. They also disclosed the whole matter to the hotel owner. The hotel owner helped them for food. Again, one Self Help Group of the locality rescued them and admitted in the residential school under State Welfare Department with the help of the Collector \& District Magistrate, Sambalpur.

\section{Case Study-2}

Madhaba Meher \& his wife Sumitra Meher residing at Chamarpada area near Farm Road in Sambalpur Town with 02 sons \& 02 daughters. Both Madhaba \& wife Sumitra are very poor, sick and bed ridden. The eldest son Manbodh Meher who is about 12 years old is a dropped out and engaged in cow \& goat grazing. Two daughters Tapaswini $\&$ Debaki are out of schools. But, 2nd son Srikanta Meher engaged in shoe polish work and feed the whole family in the last 2 years. Srikanta was working in shoe polish work in front of Sambalpur Collectorate. Srikanta comes daily with empty stomach from home \& after working sometimes he takes tiffin of Rs2/-to Rs4/-.Daily he earns about Rs.20/- and give the whole amount to the parents by which the whole family manage their feeding. Srikanta disclosed the fact that he was very much interested for study but due to poverty, want of food, family burden and sick parents he became a child labour. 


\section{Case Study-3}

Bhatli is a Block placed in Bargarh district in Odisha. Located in urban region of Odisha. It is one of the 12 blocks of Bargarh district. According to the administration records, the block number of Bhatli is 7 . The block has 84 villages and there are total 21986 homes in this Block. As per Census 2011, Bhatli's population is 90321. Out of this, 45513 are males whereas the females count 44808 here. This block has 9298 children in the age bracket of o- 6 years. Among them 4687 are boys and 4611 are girls. Literacy rate in Bhatli block is $67 \% .61331$ out of total 90321 population is literate here. In males the literacy rate is $75 \%$ as 34397 males out of total 45513 are educated while female literacy rate is $60 \%$ as 26934 out of total 44808 females are educated in this Block. The dark part is that illiteracy rate of Bhatli block is $32 \%$. Here 28990 out of total 90321 people are illiterate. Male illiteracy rate here is $24 \%$ as 11116 males out of total 45513 are illiterate. Among the females the illiteracy rate is $39 \%$ and 17874 out of total 44808 females are illiterate in this block. The count of working person of Bhatli block is 43812 while 46509 are non-working. And out of 43812 occupied people 14203 individuals are fully reliant on farming.

Here we take the case of Kalpana Deep a 12 years old daughter of Sri Jayram Deep of Mulbar village under Bhatli Block of Bargarh District. Kalpana was interested for study. But due to abject poverty father forced Kalpana to work in Brick kilns where she has to work very hard from morning to evening. Due to hard labour in the brick kiln Kalpana left home and moved here \& there in the market. Some people rescued her and rehabilitated her in short stay home in the locality.

\section{Case Study-4}

Manu Rai a 13 years old son of late Promod Rai of Cheruapara of Sambalpur Town has 5 brothers \& sisters. Father expired in 2005. Manu is the $3^{\text {rd }}$ child of his parents. After the death of father, the financial condition of Manu's family became severe. Manu's two elder brothers were working hard to manage the home \& to educate Manu but due to severe poverty they couldn't continue. At last Manu left school from classVIII. Now Manu is working in a garage in Bareipali area of Sambalpur Town for 2 years. He is getting Rs250/- in a week and helping his widow mother by giving the whole amount. He helps for family management as well as the study of 2 younger brothers \& sisters. He opined that after some years he will be trained $\&$ become a good mechanic 
\& will open a garage of his own. He also stated emotionally that he was interested for study but due to acute poverty he could not do so

\section{Case Study-5}

If we will go to the Railway Station area of Rourkela in Sundargarh District we will find Lumi Ekka a 12 years old child who does not know about her parents and engaged in begging. In the past she was staying at Chakradharpur Railway Station of Jharkhand State. She came to Rourkela 3 years ago. She begs daily in Rourkela Railway Station area. She manages her food from begging. But if on any day she does not get money or food she takes Dendrite as a food to quench her hunger. Instead of food she inhales the Dendrite solution and suppresses her hunger. The solution is available in the local market @ Rs5/- and at a times, 5 to 7 children take that solution for the purpose. Like Lumi others like, Utuni (10+), Sutia(13+) Sakati(12+) and Tuma(9+) also followed the same system of quenching their hunger.

\section{Case Study-6}

Jharagogua is a village placed in Tileibani Block of Deogarh district in Western Odisha. Located in rural part of Deogarh district of Odisha, it is one of the 246 villages of Tileibani Block of Deogarh district. According to the government records, the village code of Jharagogua is 382787. The village has 84 houses. According to Census 2011, Jharagogua's population is 361 . Out of this, 183 are males while the females count 178 here. This village has 66 children in the age bracket of o- 6 years. Out of this 32 are boys and 34 are girls. Literacy rate in Jharagogua village is 53\%. 192 out of total 361 population is literate here. In males the literacy rate is $62 \%$ as 114 males out of total 183 are educated however female literacy rate is $43 \%$ as 78 out of total 178 females are educated in this village. The dark portion is that illiteracy rate of Jharagogua village is $46 \%$. Here 169 out of total 361 individuals are illiterate. Male illiteracy rate here is $37 \%$ as 69 males out of total 183 are illiterate. Among the females the illiteracy rate is $56 \%$ and 100 out of total 178 females are illiterate in this village. The count of working person of Jharagogua village is 197 yet 164 are un-employed. And out of 197 employed people 9 persons are fully dependent on agriculture.

The village is surrounded by hills, jungles and deep forests. Wild animals like elephants, bears, monkeys and snakes are found in this area. The area was underdeveloped since independence. But after Deogarh became a separate district, in 
some areas communications, electricity has been developed partly. Jitendra Jhankar a 42 years old man lives in the said village with his wife Kanak Jhankar and 4 sons. Jitendra Jhankar is a lazy man and always drinks alcohol. He has no income as he does not work. Rather he forced his wife \& sons to work and to earn some money to provide him alcohol. He does not care for the food, milk, clothes and medicines of the family. He also forces his eldest son Sukdev Jhankar who is only 9 years old to work hard earn money. If the son refuses than Jitendra tortures him in a locked-up room without food. He also physically tortures his other sons and his wife, with weapons. The Head Instructor of Haridabahl NCLP Centre Mrs Anstacia Lakra \& Programme Manager have rescued Sukdev Jhankar and his 3 brothers from a locked-up room and reported the matter to the Superintendent of Police, Deogarh for justice. As a result of which the said Jitendra Jhankar is in Jail now since 2009.Mrs. Lakra has admitted Sukdev Jhankar in class III in the Haridabahal NCLP Centre where he was continuing his study satisfactorily. All the children are affected with skin diseases like scabies. Sukdev is very much happy with the schooling and interested for higher study. He also stated that he will become a Police Officer and will help all the families like him.

\section{Case Study-7}

Nuapada is a village located in Khariar Block of Nuapada district in Odisha. Positioned in rural part of Nuapada district of Odisha, it is one among the 116 villages of Khariar Block of Nuapada district. According to the administration records, the village code of Nuapada is 421968. The village has 101 families. According to Census 2011, Nuapada's population is 371 . Out of this, 201 are males while the females count 170 here. This village has 52 children in the age group of o- 6 years. Among them 25 are boys and 27 are girls. Literacy rate in Nuapada village is $43 \%$. 161 out of total 371 population is educated here. Among males the literacy rate is $56 \%$ as 113 males out of total 201 are educated whereas female literacy rate is $28 \%$ as 48 out of total 170 females are educated in this Village. The dark portion is that illiteracy rate of Nuapada village is shockingly high $56 \%$. Here 210 out of total 371 individuals are illiterate. Male illiteracy rate here is $43 \%$ as 88 males out of total 201 are uneducated. In females the illiteracy rate is $71 \%$ and 122 out of total 170 females are illiterate in this village. The count of occupied people of Nuapada village is 196 while 175 are non-working. And out of 196 working person 1 peoples are entirely reliant on agriculture. 
A shocking incident happened in Odisha; an eight-year-old child was tortured for months by a royal family in Khariar in Nuapada district of Western Odisha. The incident ,however, came to light following intervention of a local NGO which demanded action against Bhubaneswar Singhdeo and his wife Pushpalata Singhdeo for causing grievous injury to their domestic helper Prashant Nahak. Police said the boy ,hailing from Polsara in South Odisha, had been staying with the royal couple for the last ten months. Lying on a bed in the surgical word of the MKCG Medical College Hospital in Berhampur,8-year-old Prashant Nahak evokes sympathy among whoever comes across him. Prashant, who belongs to Sadaka village in Ganjam District, used to water the plants, wash clothes, shopped for household items and at times cooked in the house of the Singhdeo couple. Prashant said that " I tried to do all the work but if committed any mistake I was thrashed," he sobbed." once I was asked to sit on a heater, which was hot. I cried out in pain but no one listened, he said recounting his ordeal (Suffering) at Khariar. His relative said that they had sent Prashant to Khariar so he can stand on his own legs, but have found him in such condition.

Police had registered a case against the culprits and Government of Odisha had handed over the case to Crime Branch of police. Government of Odisha had also announced that all the medical expenses of the child who had sustained severe burn injuries would bear by the Government.

\section{CONCLUSION}

The future implication of child labour in Western Odisha will create multiple adverse conditions in our growing economy. The human resource development will suffer a great set back if corrective measures are not effectively implemented. Mere promulgation of an Act to eliminate child labour is not possible without generation awareness among the people to stop menace of the problem. The task is to properly implementing the programme meant to eradicate illiteracy, poverty, unemployment and generating awareness among the stakeholders. Though the policy adopted by the Government to get rid of the child labour problem and to provide them security and safe way to have a better childhood, enactment of various acts safeguard the interest of children. Convergence of other Government sponsored intervention programme related to fight against the root cause of child labour will help to a great extent to eliminate the problem from Western Odisha. 


\section{REFERENCE: -}

1. Gagan,Vishal(2005).ChildLabour.SRADHA,Vol-1,Sambalpur, Odisha.NCLP

2. Giri, V.V., (1958), Labour Problems in Indian industries, Mumbai: Asia Publishing House, p. 360.

3. Karthikeyan, Sujata (2007), Chairman's Desk. Prayas, IVth edition, Cuttack, Odisha, NCLP

4. Manual for Implementation of NCLP (2006), New Delhi Ministry of Labour \& Employment, Government of India.

5. Mishra, Dr. R.N., Problems of Child Labour in India. Published by Commonwealth Publishers, New Delhi,2004.

6. Mishra, L.D., (2009), 'Abolition of Child Labour and Right to Education',National Human Rights Commission, New Delhi, Government of India.

7. Mohapatra and Dash, (2011). "Child Labour-A product of socioeconomic problem for India, findings and preventives-A case of Bhubabaneswar (a state capital of India)", Educational Research, vol-

2, issue-6, pp-1199-1209.

8. XXXXs (2017). Labour Scenario in Odisha. Odisha Review, LXXIII (10), I\& PR. Department, Govt. of Odisha

9. XXXXs (2016). Give My Childhood. Bhubaneswar, Publishing House.

10. Orissa reference Annual (2009), Geography of Orissa, Bhubaneswar,Information \& Public Relation Department, Govt. Of Orissa.

11. Odisha- Brief Profile (CL Profile- SLI/UNICEF)

12. Raj, Nikhil \& Satpathy, Anoop Kumar, Household Food Insecurity and Child Labour: Some Evidences from Rural Orissa, Coming to Grips with Rural Child Work, Institute for Human Development, New Delhi,2002.

13. Sinha, Swapan Kumar,1991, Child Labour in Calcutta

14 Sekar, Dr Helen.R.(2015). The Child Labour (P\& R) Act,1986\& its Implementation, Noida, VVGNLI

15. Souvenir, Chikiti Mahavidyalaya (2013), Berhampur University.

16. The Child Labour (Prohibition and Regulation) Act, 1986 
17. The Hindu,3rd January,2014

18. www.labour.gov.in-schemes-child labour-census data

19. www.labdirodisha.gov.in-child labour

20. www.labdirodisha.gov.in-sli

21. www.vvgnli.gov.in

22. www.wcdodisha.gov.in/child welfare/oscp

23. www.wikivillage.in

24 www.unicef.org/protection/index-child labour. hotmail

\section{SOBRE O AUTOR}

India Ministry of Labour and Employment: DEOGARH, Odisha, IN e Sambalpur University: $\quad$ Sambalpur, $\quad$ Orissa, (https://orcid.org/) Email:drsamir.2015@gmail.com

\section{Tramitação:}

Recebido em: 29/09/2020.

Aprovado em:02/12/2020. 